\title{
Recombinant Hybrid Proteins as Biospecific Reporters for Bioluminescent Microassay
}

\author{
Ludmila A. Frank* \\ Institute of Biophysics SB RAS \\ FRC "Krasnoyarsk Science Center SB RAS" \\ 50/50 Akademgorodok, Krasnoyarsk, 660036, Russia
}

Received 14.02.2018, received in revised form 27.04.2018, accepted 28.05.2018

Light-emitting proteins, luciferases and photoproteins, are widely used as reporters in high sensitive binding assays in vitro and in vivo. The combination of luciferase and biospecific molecule with affinity to a certain target (immunoglobulin, oligonucleotide, hapten, etc.) promotes specificity of the assay. The molecules of the kind (biospecific bioluminescent labels) are usually obtained by chemical synthesis using different commercial reagents. However, this approach cannot provide homogeneity of the product; it causes the loss (sometimes essential) of specific activity of the initial molecules. As a rule chemical binding requires a thorough verification of the reaction conditions (balance of reagents, pH and temperature of the media, reaction duration, etc.) that would decrease a negative impact of the reagents and improve the yield of conjugates.

Another way to obtain combination of the kind is the creation of a hybrid protein by using genetic engineering approach. In this case a genetic construction containing, in one frame, genes coding biospecific and reporter proteins as well as sequences, coding a linker between them and sometimes auxiliary polypeptides, is created. Gene fusion approach provides easy bacterial production, hybrids homogeneity, easy purification using auxiliary polypeptides etc. The paper describes several hybrids "luciferase-biospecific polypeptide" designed in the photobiology lab of the Institute of Biophysics $S B R A S$, their construction, production and application in microassay as biospecific bioluminescent probes.

Keywords: hybrid protein, bioluminescence, photoprotein, luciferase, immunoassay.

Citation: Frank L.A. Recombinant hybrid proteins as biospecific reporters for bioluminescent microassay. J. Sib. Fed. Univ. Biol., 2018, 11(2), 166-173. DOI: 10.17516/1997-1389-0059.

(C) Siberian Federal University. All rights reserved

* Corresponding author E-mail address: 1frank@yandex.ru 


\title{
Рекомбинантные гибридные белки \\ как биоспецифические репортеры \\ для биолюминесцентного анализа
}

\author{
Л.А. Франк \\ Институт биофизики СО РАН \\ ФИЦ «Красноярский научный центр СО РАН» \\ Россия, 660036, Красноярск, Академгорок, 50/50
}

Светоизлучающие белки - лючиферазы и фотопротеины - широко используются как репортеры для высокочувствительного молекулярного анализа in vitro $u$ in vivo. Соединение (конъюгирование) люциферазы с молекулами, обладающими аффинностью к определенным мишеням (иммуноглобулинами, олигонуклеотидами, гаптенами и пр.), обеспечивает специфичность анализа. Такие молекуль (биоспецифические биолюминесиентные метки) получают химическим синтезом на основе различных коммерчески доступных реагентов, которые взаимодействуют с функииональными группами на поверхности молекул. Однако такой синтез не может обеспечить получение гомогенного аддукта, вызывает потерю (иногда значительную) функииональной активности «сшиваемых» молекул. Как правило, при получении конъюгатов химическим способом проводят длительные поиски условий синтеза (соотношение реагентов, рН и температура среды, время проведения анализа и т.n.), которые позволяют максимально уменьшить негативные последствия влияния химических реагентов и при этом иметь удовлетворительный выход целевых конъюгатов.

Другим способом получения биоспецифических меток является создание гибридных молекул с помощью генетической инженерии. Для этого получают генетическую конструкиию, в которой в одной рамке считывания последовательно находятся гены, кодирующие биоспецифический и репортерный белки, а также последовательности, кодирующие соединительный линкер, и часто различные вспомогательные полипептиды. Генетический фьюзинг обеспечивает доступную бактериальную экспрессию, гомогенность гибридных молекул, простые способы очистки с помощью вспомогательных полипептидных фрагментов и т.д. В данной работе описан ряд гибридов «люиифераза-биоспецифический белок», созданных в лаборатории фотобиологии Института биофизики СО РАН, их дизайн, получение и применение в качестве биоспецифических биолюминесцентных меток в микроанализе.

Ключевые слова: гибридный белок, биолюминесценция, фотопротеин, люцифераза, иммуноанализ.

\section{Introduction}

The hybrid (chimeric or fusion) proteins are artificial proteins genetically obtained by fusing several DNA coding parent proteins or oligopep- tides in the one frame. The DNA is expressed in host cells (usually microbe) and the resulting protein simultaneously exhibits the properties of all parent proteins or oligopeptides. 
Hybrids can be conditionally divided into two groups:

1) Hybrids of the target protein and auxiliary polypeptide, that would provide: a) directed expression of the hybrid into cytoplasm or periplasmic space of the host cell or into culture medium that can be required for proper protein folding; and (or) b) possibility for effective isolation by affine chromatography. Auxiliary polypeptides are often deleted at the last stage of purification.

2) Multifunctional hybrids which consist of several domains, each being valuable. Biospecific activity of domains in hybrids is usually close to the one of initial proteins, whereas the chemical synthesis of multifunctional proteins inevitably damages the activity due to the reagents nonspecificity. Often, the target multifunctional hybrid proteins also contain additional auxiliary polypeptides for fast and simple purification.

The studies on bioluminescent systems of various luminous organisms are being carried out in the laboratory of photobiology of the Institute of Biophysics SB RAS for more than 30 years. Of special interest are the investigations of the so-called coelenterazine-dependent systems where bioluminescent reaction arises as a result of oxidation of the substrate (coelenterazine) with oxygen catalyzed by the specific proteins - luciferases or $\mathrm{Ca}^{2+}$-regulated photoproteins (Markova, Vysotski, 2015). Apart from fundamental research, considerable efforts have been made with regard to analytical applications of those in biomedicine (see e.g. Frank, Krasitskaya, 2014; Frank et al., 2017). Practical interest to light-emitting proteins is conditioned by the high quantum yield of the reactions catalyzed by luciferases and a high signal-to-noise ratio, potentially providing high sensitivity of the assays based on these enzymes as reporters. Recombinant $\mathrm{Ca}^{2+}$-regulated photoprotein obelin from the hydroid Obelia longissima, luciferases from soft coral Renilla muelleri and copepod Metridia longa were applied as reporters in both - in vitro and in vivo analytical systems. To develop highly specific and sensitive probe on their basis, the hybrid protein technology was also applied. The paper presents several examples of creation and analytical application of hybrid bioluminescent proteins (Fig. 1).

\section{Auxiliary polypeptides for target protein production}

Recombinant Escherichia coli cells are the most frequently used host employed for fast and inexpensive production of the target protein. Bacteria-produced proteins can be located in the soluble state in cytoplasm, or aggregated in insoluble nonfunctional protein (inclusion bodies), or directed into periplasmic space or into culture medium. Serious problem is the absence of post-translational modifications in bacteria, so the expressed eukaryotic proteins may fold incorrectly and lack biospecific activity. There is no universal approach to provide the expression of the pure, soluble and functional protein: the expression conditions are mostly found empirically. Modern biotechnology offers a number of approaches to overcome the problem. The Table summarizes our experience on the creation of bioluminescent hybrid proteins, their expression and purification.

As we found several hybrids of the type biospecific protein-obelin (Fig. 1, a-c) that were expressed as insoluble aggregates demonstrate the activity of both domains (Table, No. 1-3) (Frank et al., 1996; Eremeeva et al., 2010; Bashmakova et al., 2017). Probably, it is conditioned by the amino acids sequences of the domain - there are no S-S bonds in the structures of the added proteins (proZZ, cgreGFP, streptavidin). Apo-obelin independently forms a photoprotein complex with coelenterazine at 


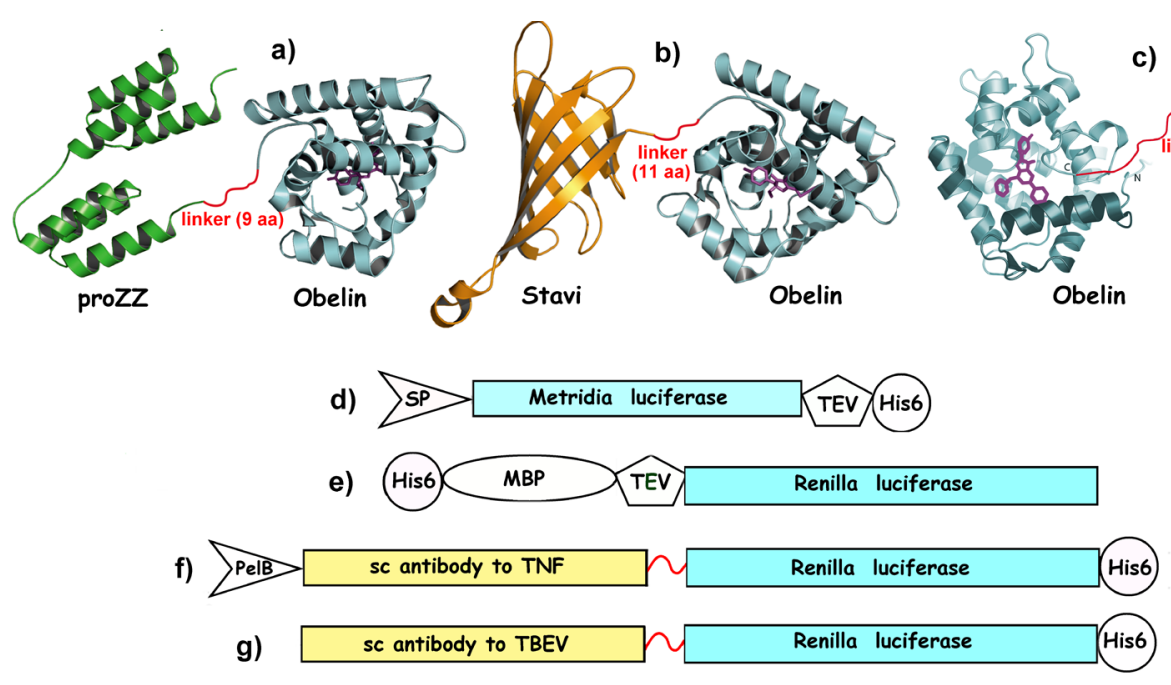

Fig. 1. Hybrid images: protein A (double Z fragment)-obelin (a), streptavidin (Stavi) - obelin (b), obelin - Clytia gregaria GFP (cgreGFP) (c) structures, depicted from the known pdb structures of separated domains and flexible linker inbetween (in red). Obelin structure is shown in light-blue, peroxycoelenterazine in the molecule center in purple as a stick model; (d-g): composition of hybrids involving luciferase (cyan bars), biospecific proteins (yellow bars) and auxiliary polypeptides (no color). SP, PelB - signal polypeptides; TEV - TEV protease site; His6 - hexahistidine fragment; MBP - maltose-binding protein

a final incubation under reducing conditions. It should be noted here that obelin can be extended with a polypeptide from $\mathrm{N}$-end without loss of bioluminescent activity, whereas the extension of the C-end mostly causes photoprotein's instability (Eremeeva et al., 2014). We found, that the above hybrids have several advantages as compared to similar chemical conjugates: the easiest way of preparation, maximum retention of properties of the initial (parent) protein and as a result the higher sensitivity of the assay on their base.

In our laboratory, the cDNAs of several isoforms of luciferase from copepod Metridia longa were cloned (Markova et al., 2004). The luciferases expressed in E. coli cells in insoluble state were shown to substantially lose their bioluminescent activity. Besides, Metridia luciferases are cysteine-rich proteins that form random S-S bonds yielding insoluble polymeric high-molecular aggregates. Despite considerable efforts to refold the proteins, some of them were not successful (Borisova et al.,
2008). The expression in insect cells with the use of a baculovirus expression system is a very powerful tool to express recombinant eukaryotic proteins. The eukaryotic insect host cells perform most of the post-translational modifications of proteins occurring in eukaryotes as well as the correct formation of disulfide bonds. We found that the expression of Metridia luciferase (MLuc) in insect (Sf9) cells (Table, No. 4) using the baculovirus expression system yields a functionally active protein (Stepanyuk et al., 2008). As far as Metridia cDNA was cloned with its own natural signal peptide (17 aa), the protein was secreted by the insect cells into the culture media with a simultaneous cleavage of the signal peptide. Besides after Metridia cDNA there were the sequences, coding hexahystidine (Histag) to provide its fast and easy purification by the metal-affinity chromatography. Between Histag and luciferase there was also the 7 aa peptide ENLYFQS - specific site of the protease from tobacco etch virus (TEV-protease). TEV-protease was used at the last step of the 
Table. Hybrid bioluminescence proteins composition, purpose and application

\begin{tabular}{|c|c|c|c|c|}
\hline No & Hybrid composition & $\begin{array}{l}\text { Hybrid or its domains } \\
\text { (function) }\end{array}$ & $\begin{array}{c}\text { Host cell; } \\
\text { hybrid destination }\end{array}$ & Reference \\
\hline 1 & $\begin{array}{l}\text { Streptavidin-obelin } \\
\text { (Stavi-Obe) }\end{array}$ & $\begin{array}{l}\text { Probe to biotin-labeled } \\
\text { molecules }\end{array}$ & $\begin{array}{l}\text { E. coli BL21-Codon } \\
\text { Plus (DE3); } \\
\text { inclusion bodies }\end{array}$ & $\begin{array}{l}\text { Bashmakova et al., } \\
2017\end{array}$ \\
\hline 2 & $\begin{array}{l}\text { Protein A from } \\
\text { Staphylococcus } \\
\text { aureus-obelin } \\
\text { (proZZ-Obe) }\end{array}$ & $\begin{array}{l}\text { Probe to any IgG due to protein } \\
\text { A affinity to Fc fragment }\end{array}$ & $\begin{array}{l}\text { E. coli BL21-Codon } \\
\text { Plus (DE3); inclusion } \\
\text { bodies }\end{array}$ & Frank et al., 1996 \\
\hline 3 & $\begin{array}{l}\text { Obelin-Green } \\
\text { Fluorescence Protein } \\
\text { from Clytia gregaria } \\
\text { (Obe-cgreGFP) }\end{array}$ & $\begin{array}{l}\text { Model hybrid for BRET } \\
\text { investigation }\end{array}$ & $\begin{array}{l}\text { E. coli XL1-Blue; } \\
\text { inclusion bodies }\end{array}$ & Eremeeva et al., 2010 \\
\hline 4 & $\begin{array}{l}\text { Signal peptide-- } \\
\text { luciferase Metridia } \\
\text { longa-TEV-Histag }\end{array}$ & $\begin{array}{l}\text { Production of Metridia longa } \\
\text { (MLuc164) luciferase of the } \\
\text { highest activity } \\
\text { Histag: His6 oligopeptide } \\
\text { (purification by metal-affinity } \\
\text { chromatography); TEV: } \\
\text { polypeptide ENLYFQS - } \\
\text { tobacco etch virus (TEV) } \\
\text { enteropeptidase site (deletion of } \\
\text { Histag) }\end{array}$ & $\begin{array}{l}\text { Insect cells (Sf9); } \\
\text { Culture media }\end{array}$ & $\begin{array}{l}\text { Stepanyuk et al., } \\
2008\end{array}$ \\
\hline 5 & $\begin{array}{l}\text { Histag-MBP-TEV- } \\
\text { luciferase Renilla } \\
\text { muelleri } 7\end{array}$ & $\begin{array}{l}\text { Production of Renilla muelleri7 } \\
\text { luciferase; } \\
\text { MBP: maltose-binding protein } \\
\text { (increase of hybrid solubility in } \\
\text { cytoplasm); TEV (deletion of } \\
\text { auxiliary fragment Histag-MBP) }\end{array}$ & $\begin{array}{l}\text { E. coli BL21- } \\
\text { CodonPlus (DE3)- } \\
\text { RIPL; cytoplasm }\end{array}$ & $\begin{array}{l}\text { Stepanyuk et al., } \\
2010\end{array}$ \\
\hline 6 & $\begin{array}{l}\text { PelB-anti-tumor } \\
\text { necrosis factor } \\
\text { (TNF) single-chain } \\
\text { antibody-luciferase } \\
\text { Renilla muelleri7- } \\
\text { Histag (G1-Rm7) }\end{array}$ & $\begin{array}{l}\text { Probe for TNF immunoassay. } \\
\text { PelB-oligopeptide (direction of } \\
\text { hybrid into periplasmic space) }\end{array}$ & $\begin{array}{l}\text { E. coli } \mathrm{HB} 2151 ; \\
\text { periplasmic space }\end{array}$ & Patent of RF, 2014 \\
\hline 7 & $\begin{array}{l}\text { Anti-tick born } \\
\text { encephalitis virus } \\
\text { (TBEV) antibody- } \\
\text { luciferase Renilla } \\
\text { muelleri7-Histag } \\
\text { (14D5a-Rm7) }\end{array}$ & Probe for TBEV immunoassay & $\begin{array}{l}\text { E. coli } \text { Rosetta } \\
\text { gami2; } \\
\text { cytoplasm }\end{array}$ & Burakova et al., 2015 \\
\hline
\end{tabular}

purification to eliminate His-tag fragment. So, to produce a more active Metridia luciferase (the protein produced in insect cells has a 3.5 -fold greater bioluminescence) we used 3 auxiliary polypeptides (Fig. 1, d) and insect host cells. Similar approach was used to produce new MLuc isoforms with unique properties (Markova et al., 2015; Larionova et al., 2017). Of note is that the use of insect ( $\mathrm{Sf} 9$ ) cells as a host organism is a rather expensive approach and needs special devices and materials.

To obtain the recombinant luciferase Renilla muelleri (RmLuc7) (Table, No. 5) in cytoplasm of $E$. coli cells in an active soluble state, another approach was used (Stepanyuk et al., 2010). The protein was extended from the N-end with 
3 auxiliary polypeptides: Histag for purification, the maltose-binding protein (MBP) for protein solubility and the specific site of TEV-protease (Fig. 1, e). The attaching of MBP to increase recombinant protein's solubility is a wildly used approach, since mechanism of the effect is not known. The same metal-affinity chromatography was used twice: to purify the whole hybrid and to remove auxiliary polypeptide Histag-MBP after TEV-protease cleavage.

\section{Multifunctional hybrids:}

\section{production and application as reporters in microassay}

The chemical synthesis of conjugates luciferase-biospecific molecule as a probe for detecting the corresponding target causes a significant loss of luciferase (not photoprotein!) bioluminescent activity due to non-specificity of chemical reagents. To develop a bioluminescent probe based on a thermostable variant Renilla muelleri luciferase ( $\mathrm{Rm} 7)$, the genetic fusing technology was the most appropriate approach.

Hybrid G1-Rm7 (Table, No. 6) contains the luciferase $\mathrm{Rm} 7$ as a signal domain and a singlechain antibody G1 to tumor necrosis factor alpha $(\alpha \mathrm{TNF})$ as a biospecific domain (Patent of RF, 2014). The proper folding of anti-TNF antibody requires the formation of S-S bond (Vikhrova et al., 2011). For this purpose, the pelB-leader sequence which directed protein to the bacterial periplasm was attached to the $\mathrm{N}$-end of the hybrid. Under the process, the pelB is removed by a signal peptidase and Cys residues are oxidized forming the S-S bond. To provide independent domains' folding and exhibition of properties, the flexible linkers (GGGGS) $)_{2}$ and (GGS) $)_{2}$ were inserted between antibody $\mathrm{G} 1$ chains and between G1 and Rm7, correspondingly. The target hybrid G1-Rm7 has also Histag fragment at the C-end for purification (Fig. 1, f). Protein was expressed in E. coli, extracted from periplasm and purified with metal-affine chromatography. The model bioluminescent solid-phase microassay of aTNF proved that both domains retain their initial properties, providing $\alpha \mathrm{TNF}$ detection in concentration of several $\mathrm{ng} / \mathrm{mL}$ (Patent RF, 2014). It was found however, that expression into periplasmic area produces a very little quantity of the target hybrid.

The other hybrid of the kind, 14D5a-Rm7 (Table, No. 7), contains as a biospecific domain 14D5a - variable domain of murine monoclonal antibody with a high affinity to envelope glycoprotein E of tick-born encephalitis virus (TBEV) (Burakova et al., 2015). In this case, we refused from periplasmic expression (no pelB in the construction, Fig. 1, g) and used the E. coli strain Rosetta-gami as host cells due to its enhanced disulfide bond formation in the cytoplasm. The protein was mainly accumulated in soluble state in cytoplasm. It was purified using Histag on the C-end and the typical yield of the protein was 2-3 mg per $1 \mathrm{~L}$ cell culture using the LB medium. Hybrid affinity to the virus envelope protein $E\left(k_{\text {aff }}=2.65 \times 10^{7} \mathrm{M}^{-1}\right)$ was close to the one of unmodified recombinant $14 \mathrm{D} 5 \mathrm{a}\left(\mathrm{k}_{\mathrm{aff}}=1.6 \times 10^{7}\right.$ $\mathrm{M}^{-1}$ (Baykov et al., 2014)), which indicates a correct antibody folding. Despite that luciferase in the hybrid is extended from both - N- and $\mathrm{C}$-end its bioluminescent activity is rather high. The apparent (calculated by bioluminescence with coelenterazine as a substrate) MichaelisMenten constants $(\mathrm{Km})$ are 0.91 and $3.98 \mu \mathrm{M}$ for the fusion protein and free luciferase $\mathrm{Rm} 7$, respectively. The apparent rate constants, which characterize the efficiency of an enzyme, were 161 and $49 \mu \mathrm{M}^{-1} \mathrm{~s}^{-1}$ for Rm7 and 14D5a-Rm7, respectively. So, the fusion protein oxidizes coelenterazine only approximately three times less effectively than the luciferase. Model solidphase immunoassay of TBEV in laboratory- 
cultivated ticks allows the detection of almost $10^{4}-10^{5}$ virus particles or about $0.1 \mathrm{pg}$ virions. It is close to capability of RT-qPCR method, but the developed bioluminescent immunoassay is much simpler at that.

Presently the technology to produce hybrid proteins is one of the most used in molecular biology and biotechnology. The methods, materials and approaches developed in the field allow the production of a huge amount of unique multifunctional proteins with new useful properties applicable in different areas. There are not only proteins for application as high sensitive probes for in vitro and in vivo assays, but for example, artificial zinc fingers-nuclease or TALE-nuclease hybrids used for genome redaction investigation.

\section{Acknowledgments}

The work was funded by RFBR, Government of Krasnoyarsk Territory, Krasnoyarsk Region Science and Technology Support Fund (projects No. 16-44-240648 p_a) and by the state budget allocated to the fundamental research at the Russian Academy of Sciences, project No. 03562017-0017.

\section{References}

Bashmakova E.E., Krasitskaya V.V., Kudryavtsev A.N., Grigorenko V.G., Frank L.A. (2017) Hybrid minimal core streptavidin-obelin as a versatile reporter for bioluminescence-based bioassay. Photochem. Photobiol., 93(2): 548-552

Baykov I.K., Matveev A.L., Stronin O.V., Ryzhikov A.B., Matveev L.E., Kasakin M.F., Richter V.A., Tikunova N.V. (2014) A protective chimeric antibody to tick-borne encephalitis. Vaccine, 32: 3589-3594

Borisova V.V., Frank L.A., Markova S.V., Burakova L.P., Vysotski E.S. (2008) Recombinant Metridia luciferase isoforms: expression, refolding and applicability for in vitro assay. Photochem. Photobiol. Sci., 7: 1025-1031

Burakova L.P., Kudryavtsev A.N., Stepanyuk G.A., Baykov I.K., Morozova V.V., Tikunova N.V., Dubova M.A., Lyapustin V.N., Yakimenko V.V., Frank L.A. (2015) Bioluminescent detection probe for tick-borne encephalitis virus immunoassay. Anal. Bioanal. Chem., 407: 5417-5423

Eremeeva E.V., Frank L.A., Markova S.V., Vysotski E.S. (2010) $\mathrm{Ca}^{2+}$-regulated photoprotein obelin as N-terminal partner in the fusion proteins. J. Sib. Fed. Univ., Biol., 4: 372-383

Eremeeva E.V., Burakova L.P., Krasitskaya V.V., Kudryavtsev A.N., Shimomura O., Frank L.A. (2014) Hydrogen-bond network between C-terminus and Arg from the first $\alpha$-helix stabilizes a photoprotein molecule. Photochem. Photobiol. Sci., 13: 541-547

Frank L.A., Bashmakova E.E., Krasitskaya V.V., Kudryavtsev A.N. (2017) Genetically modified coelenterazine-dependent luciferases as reporters for in vitro assay. J. Sib. Fed. Univ., Biol., 10(2): $199-210$

Frank L.A., Illarionova V.A., Vysotski E.S. (1996) Use of proZZ-obelin fusion protein in bioluminescent immunoassay. Biochem. Biophys. Res. Commun., 219: 475-479

Frank L.A., Krasitskaya V.V. (2014) Application of enzyme bioluminescence for medical diagnostics. Adv. Biochem. Eng. Biotechnol., 144: 175-197

Larionova M.D., Markova S.V., Vysotski E.S. (2017) The novel extremely psychrophilic luciferase from Metridia longa: Properties of a high-purity protein produced in insect cells. Biochem. Biophys. Res. Commun., 483: 772-778 
Markova S.V., Golz S., Frank L.A., Kalthof B., Vysotski E.S. (2004) Cloning and expression of cDNA for a luciferase from the marine copepod Metridia longa. A novel secreted bioluminescent reporter enzyme. J. Biol. Chem., 279(5): 3212-3217

Markova S.V., Larionova M.D., Burakova L.P., Vysotski E.S. (2015) The smallest natural highactive luciferase: cloning and characterization of novel 16.5-kDa luciferase from copepod Metridia longa. Biochem. Biophys. Res. Commun., 457: 77-82

Markova S.V., Vysotski E.S. (2015) Coelenterazine-dependent luciferases. Biochemistry (Mosc), 80(6): 714-732

Patent of RF (2014) No. 2513686

Stepanyuk G.A., Xu H., Wu C.-K., Markova S.V., Lee J., Vysotski E.S., Wang B.-C. (2008) Expression, purification and characterization of the secreted luciferase of the copepod Metridia longa from Sf9 insect cells. Prot. Expr. Purif., 61: 142-148

Stepanyuk G.A., Unch J., Malikova N.P., Markova S.V., Lee J., Vysotski E.S. (2010) Coelenterazine-v ligated to $\mathrm{Ca}^{2+}$-triggered coelenterazine-binding protein is a stable and efficient substrate of the redshifted mutant of Renilla muelleri luciferase. Anal. Bioanal. Chem., 398: 1809-1817

Vikhrova M.A., Batanova T.A., Lebedev L.R., Shingarova L.N., Frank L.A., Kirpichnikov M.P., Tikunova N.V. (2011) Human single-chain antibodies specific to the tumor necrosis factor. Russ. J. Bioorgan. Chem., 37(3): 298-306 